\title{
POSISI BAHASA ARAB DI DUNIA ISLAM
}

Sakti Agung Panineungan England

Sekolah Tinggi Agama Islam Negeri (STAIN) Sorong, Papua Barat, Indonesia

Email : saktiengland999@gmail.com

\begin{abstract}
Bahasa Arab sudah dikenal sejak masuknya islam ke wilayah tanah air nusantara. Bagi bangsa Indonesia, khususnya umat islam, bahasa Arab bukanlah bahasa asing karena muatannya menyatu dengan kebutuhan umat islam. Di lingkungan tertentu, sebagian orang mengetahui, bahasa Arab merupakan bahasa penerus filsafat dan kebudayaan Yunani untuk kemudian disosialisasikan ke dunia Barat. Bahasa Arab juga bahasa komunikasi dalam hubungan internasional yang kedudukan dan fungsinya dimantapkan oleh keputusan besar di perserikatan bangsa-bangsa (PBB) sebagai bahasa resmi.
\end{abstract}

\section{PENDAHULUAN}

Dalam menyelesaikan tugas membuat rangkuman tentang posisi bahasa Arab di dunia islam. Maka saya sebagai penyusun membuat rangkuman ini dengan sebaik-baiknya. Tujuannya agar pembaca memahami seperti apa posisi bahasa Arab di dunia islam.

Sedikit ulasan mengenai posisi bahasa Arab di dunia yaitu bahasa Arab baik yang berbentuk klasik maupun modern, mempunyai peranan yang sangat penting dalam bidang agama [islam], ilmu pengetahuan, dan hubungan internasional. Peranannya juga sangat penting dalam pembinaan dan pengembangan kebudayaan nasional.

\section{PERANAN BAHASA ARAB DALAM AGAMA}

Rakyat Indonesia yang tersebar di berbagai kepulauan di seluruh nusantara sebagian besar memeluk islam sebagai agama dan keyakinannya. 
Sebagaimana diketahui bahwa islam adalah agama wahyu yang diturunkan kepada Nabi Muhammad Saw. sebagai utusan terakhir dihimpun menjadi kitab suci Al-qur'an yang berbahasa Arab. Begitu pula hadist yang merupakan penjelasan dan penafsiran Al-qur'an dihimpun dan disusun dalam bahasa Arab.

Dalam sejarah perkembangan agama samawi atau agama wahyu, tidak terdapat kitab suci yang masih asli bahasanya, kecuali Al-qur'an. Ayat-ayat Alqur'an yang diturunkan dalam dua periode, yaitu periode sebelum hijrah dari Makkah ke Madinah yang lazim disebut sebagai surat-surat Makkiyyah, dan periode setelah hijrah yang lazim disebut sebagai surat-surat Madaniyyah, masih tetap utuh dalam bahasa aslinya. Keaslian atau otentisitas ini merupakan mukjizat sebagaimana yang Allah janjikan. Karena itu, dapat dikatakan bahwa setiap terjemahan Al-qur'an atau alih bahasa dari bahara Arab atau tafsirannya ke dalam bahasa selain bahasa Arab tidak dapat disebut Al-qur'an. la hanya dapat dikatakan sebagai terjemahan atau tafsir, ini merupakan kebutuhan yang sangat utama. Juga, mempelajari bahasa Arab mempunyai tujuan yang suci, yaitu untuk mempelajari dan memperdalam pemahaman islam dari sumber yang asli.

Isi Al-qur'an tidak hanya mengandung masalah kepercayaan (akidah), tetapi juga syariah yaitu persoalan yang membahas hukum-hukum yang ditetapkan Allah dan dicontohkan oleh Rasulnya. Karena itu Al-qur'an dan hadist merupakan sumber pokok dari akidah dan syariah islamiyah. Akidah dan syariah islamiyah yang merupakan isi kandungan Al-qur'an dan hadist tidak mudah dipahami oleh setiap orang [awam], sehingga untuk dapat memahaminya diperlukan para ahli atau mujtahidin. Seiring dengan timbulnya berbagai masalah keagamaan setelah Nabi Muhammad Saw. wafat dan setelah periode khulafa ar-rasyidin, timbullah peran ulama yang berjasa 
dalam usaha-usaha memahami dan mensosialisasikan syariah, baik yang berkenan dengan ibadah, muamalah, maupun jinayah. Jadi, jelaslah bahwa selain bersumber hukum pokok pada Al-qur'an dan hadist, ulama juga menambahkan sumber hukum lain yang dikembangkan oleh pemikiran mereka, yaitu ijtihad. ljtihad yakni pengarahan pikiran secara sungguhsungguh untuk menemukan dan mengambil kesimpulan hukum berdasarkan Al-qur'an dan hadist. Uraian dan pembahasan mengenai sumber-sumber hukum tersebut banyak ditulis oleh ulama terdahulu dalam kitab-kitab klasik yang berbahasa arab.

Peranan bahasa arab yang fenomenal dalam agama tampak jelas dalam pelaksanaan upacara ibadah ritual seperti ungakapan-ungkapan untuk memanggil atau mengajak shalat yang disebut adzan dan iqamat yang selalu berkumandang dari menara-menara masjid di seluruh dunia islam. Bahkan, sudah banyak bukti bahwa ada banyak muallaf yang tertarik ke dalam islam setelah mendengar seruan untuk sholat itu. Karena sifatnya yang ta'abbudi [ritual], adzan dan iqamat harus diucapkan dalam bahasa Arab. Selain adzan bacaan-bacaan di dalam shalat pun harus diucapkan dalam bahasa Arab sesuai dengan tuntunan Nabi Muhammad Saw.

Atas izin dan kehendak Allah, usaha-usaha untuk men-jauhkan umat muslim dari bahasa Arab ternyata gagal, sehingga dalam masalah ibadah pengucapan dengan bahasa Arab tidak pernah ada perubahan. Hingga kini, tidak pernah ada usaha-usaha lanjutan sebagaimana yang pernah dilakukan oleh Musthafa Kamal Attaturk, karena mereka sadar bahwa usaha semacam ini pasti menemui kegagalan. Selain harus mampu mengucapkan bahasa Arab sekurang-kurangnya untuk keperluan upacara ibadah, seorang muslim juga harus dapat memahami dan menghayati makna yang diucapkannya itu. Menurut islam, ibadah adalah upaya sungguh-sungguh yang dilakukan 
seorang muslim untuk mengadakan hubungan antara makhluk dan khaliknya yang lazim disebut hablun minallah.

\section{KESIMPULAN}

Bahasa Arab adalah bahasa asing sebagai suatu komunikasi verbal yang dipakai diseluruh dunia yang dipelajari untuk saling membagi pengetahuan dalam rangka memelihara keberadaan tradisi dan kebudayaan dan khususnya untuk memelihara hubungan manusia.

\section{DAFTAR PUSTAKA}

Wekke, Ismail Suardi. (2011). Dukungan Sosial, Optimisme \& Prestasi Belajar Bahasa Arab. Cet.l; Makassar: Universitas Agama Negeri Alauddin Press.

Muhammad, Ismail. (2012). Posisi Pembelajaran Bahasa Arab Dalam Klasifikasi Ilmu Bahasa Arab. Halaman: 68-78; Banda Aceh: Institut Agama Islam Negeri Ar-Raniry.

Izzan, Ahmad. (2007). Metodologi pembelajaran bahasa Arab. Cet.Il; Bandung: Humaniora. 